\title{
The role of market power in economic growth: an analysis of the differences between EU and US competition policy theory, practice and outcomes
}

Stephane Ciriani, Orange

Marc Lebourges, Orange

\begin{abstract}
The European Union has experienced weak economic performance over the past 15 years, compared to the United States. In order to restore investment, innovation, and therefore growth, the European Commission seeks to raise the level of static competition in all markets. The Commission's economic policy is largely determined by its competition policy. This policy is derived from its doctrine on competition law, which regards the exercise of market power as a source of inefficiency and advocates that its effects should be banned. By contrast, the United States competition authorities, under the influence of the Chicago School, consider that market power is a necessary incentive to invest and a fair return on investment. Recent findings in economic growth theory, which state that increased competition intensity may harm endogenous innovation, provide a theoretical basis to support the United States approach and call for a review of European doctrine.
\end{abstract}

\section{Keywords}

Antitrust; competition; endogenous growth; innovation; market power; market structure.

\section{JEL classification}

L10; L40; O30; O40. 
Economic growth in the European Union (EU) over the past fifteen years has been weak by international standards, and the pace of recovery from the financial crisis is slow. The economy of the EU has started to lose ground against the United States (US) since the mid-1990s. The European Commission has acknowledged that the weak economic performance of the EU is notably due to low investment in new technologies, and pointed at the need to increase the innovation effort in order to foster economic growth in the EU and to compete on a global scale. The economic policy of the European Commission is largely influenced by the principles and actions of the European competition authorities. The Commission's economic doctrine posits that the ever-increasing level of competition intensity invariably leads to higher investment in innovation, and that competition policy is a major instrument to foster economic growth. The core principle of the European competition policy is that market power, although not considered unlawful, is the main source of economic inefficiency, and its effects should therefore be removed.

An analysis of the principles and the effects of this economic doctrine is proposed, in order to examine whether the Commission's policy is the most appropriate to reverse the structural trends of investment and productivity in the EU. The first section describes European Commission's economic doctrine and its views on the role and the effects of competition policy, on the basis of reports and communications published by the European authorities. This section shows that the European Commission applies its competition policy in order to increase the level of static competition intensity in all markets (i.e. to eliminate all the effects of the exercise of market power), with the objective to promote aggregate investment in equipment, technology and innovation.

The second section provides a comparative analysis of the principles and the practices of the competition courts and agencies in the US and the EU. It highlights the differences between the US and the European authorities over the purpose of competition law and over the way authorities address market power. The European competition doctrine attempts to prevent the emergence and to ban the exercise of market power, market power being considered as a factor of inefficiency per se. By contrast, the US authorities tend to encourage the effects of market power, after their doctrine experienced an in-depth review in the 1970s, led by the Chicago School of economics.

The third section presents recent findings in the fields of economic growth theory and innovation economics, which show that market power is both a necessary incentive and a fair return on investment and that a systematic increase in the level of static competition might end up discouraging endogenous innovation.

A fourth section provides an assessment of the consistency of the European and the US doctrine on competition law and competition policy with these recent results. It concludes that the European Commission should review and update its doctrine in order to promote robust and sustainable economic growth in the EU.

\section{The European Commission's doctrine on the role and effects of competition policy}

This first section describes the European Commission's economic doctrine on the nature of competition, the concept of market power, and the role of competition policy as the main engine of economic growth. This economic doctrine is made visible and explicit through a set of quotes extracted from a body of documents published by various European Commission entities over the last ten years. The analysis of these quotes helps formalise the core principles of the Commission's economic doctrine, which underlies its competition policy. This analysis also demonstrates how the Commission applies these principles in order to tackle European weaknesses in terms of investment in technology and innovation and to meet the objectives of the Europe 2020 Strategy, whereby the Commission notably 
commits to 'develop an economy based on knowledge and innovation', and to promote a 'more competitive economy'. This section provides evidence that in order to stimulate aggregate investment, the European Commission aims to increase the level of static competition in all markets, based on the doctrine that more intense competition invariably leads to higher rates of innovation and increased productivity. In the rest of this article, the term 'market power' refers to 'the ability to set price above marginal cost' as defined by Landes and Posner (1981), who state that if 'a firm's price is above its marginal cost, the implication is that the firm does not face perfect competition, i.e., that it has at least some market power'.

\subsection{Competition policy is the core of the European Commission's economic doctrine}

In its most recent Report on Competition Policy, the European Commission (2015a) outlines a primary objective of its competition policy, which consists in being 'vigilant that manufacturers of important input products do not acquire the power to raise prices above competitive levels through mergers'. The European Commission (2012) advocates competition as the main driver of economic growth and regards competition policy as the main instrument to support productivity and competitiveness. Competition is viewed as 'the most important single driver of innovation, competitiveness and therefore growth', while 'competition policy can create the conditions for growth and employment across Europe'. Moreover, 'promoting strong competition enforcement in Europe -at every level- is a powerful energiser for the economy because its effects can be immediate'.

The European Parliament (2015) recently recalled that competition policy remains at the core of the economic policy of the EU-28. It stated that 'for a long time, competition policy has been providing a prevailing conceptual model influencing policy developments at EU level, which is still at work nowadays', and that 'there is actually little call for a radical overhaul in this respect'. The European Commission (2012a) considers that competition always drives economic growth and maximises social welfare, as 'competition enforcement and advocacy serve wider long-term objectives such as enhancing consumer welfare, supporting the EU's growth, jobs and competitiveness in line with the Europe 2020 Strategy for smart, sustainable and inclusive growth'.

The Commission (2004a) has identified competition as the major policy instrument to foster economic growth, stating that 'vigorous competition is a key driver for competitiveness and economic growth', which 'generates pressures on firms to innovate and (...) improve their cost structure and reap productivity gains.' Competition is regarded as a 'continuous structural adaptation process' and 'a vital market process which rewards firms offering lower prices, better quality, new products, and greater choice'. For the Commission, competition is an evolutionary process that selects the most efficient firms: 'competition leads to the introduction of improved products and processes, weeding out inefficient firms and reallocating productive resources from retreating firms to new entrants or more efficient competitors'. Competition separates efficient firms from inefficient ones and reallocates inputs and financial resources to the most efficient activities. By doing so, the most productive sectors are endowed with greater resources at a lower price, allowing them to invest in private fixed assets.

A crucial argument raised by the European Commission in favour of its competition policy is that it reallocates resources from inefficient sectors to the most productive ones. This process generates productivity gains and spreads them across sectors. The Commission (2011a) aims to support 'structural change towards dynamic sectors and high-productivity activities', through the reallocation of production factors and financial capital from 'slow-growing to dynamic firms and sectors', and from 'non-tradable to tradable sector', hence, from services to industrial sectors. 
This reallocation depends on the 'strict implementation of competition policies at both EU and national level'. The cross-sector reallocation of these productive resources depends on markets' ability to give investors 'adequate price signals'. Since price signals are fully accurate only under perfect competition, the productive inputs will move towards the most efficient and productive sectors provided that the markets actually tend towards perfect competition. A fall in the price of intermediate inputs which are produced by service sectors should result from a convergence of markets towards their perfectly competitive frame.

\subsection{For the European Commission, macroeconomic performance depends on the control of markets by the competition authorities}

According to the European Parliament (2013), the instruments of competition policy (antitrust, merger control, State aid and ex-ante regulation of specific sectors) promote 'growth drivers such as productivity, innovation, investment and low prices'. Following this rationale, the competition policy enforced by the Commission's agencies is assumed to achieve static efficiency through price competition that leads to equating prices and marginal costs, simultaneously generating dynamic efficiencies by fostering innovation through an evolutionary process of rivalry.

The European authorities believe that in order for competition to fully deliver its growth-enhancing effect, markets have to be organised by competition authorities. The European Commission (2011a) recommends to strengthen 'the administrative capacity of the competition authority.' The policy priority to 'create a businessfriendly environment conducive to improving the economy's competitiveness' has to be achieved through the 'efficient functioning of competition authorities, market regulators and judicial authorities'. The European Commission (2015a) outlines that technological progress stems directly from innovation and that a strict enforcement of antitrust law is the primary condition to stimulate innovation: 'vibrant competition is essential to stimulate innovation and spread the benefits of technological development among Europe's citizens', and 'effective enforcement of antitrust and merger policy makes it easier for small businesses to thrive and gain access to markets in sectors dominated by network effects'.

\subsection{The Commission acknowledges that the European Union has been losing ground in terms of competitiveness because of low investment in innovation even prior to the financial crisis}

The European Commission (2015b) acknowledges that 'productivity growth remains slow' in the EU, 'affecting competitiveness and living standards', and that the recovery from the post-crisis recession remains moderate. According to Van Ark and Erumban (2015), the EU has had a slower productivity growth rate than the US since the early 1990s, which was largely due to a slower pace of innovation and technology adoption, mainly in the services sector. The Commission acknowledges that the economic weaknesses of the EU might be related to structural inefficiencies rather than being just the outcome of the financial crisis which broke out in 2008.

The European Commission (2010a) indicates that 'even before the crisis, there were areas where Europe was not progressing fast enough relative to the rest of the world', and that 'Europe's average growth rate has been structurally lower than [its] main economic partners, largely due to a productivity gap that has widened over the last decade'. This productivity gap is notably due to 'lower levels of investment in R\&D and innovation', and 'insufficient use of information and communications technologies'. 
The European Commission (2013a) has more recently pointed at the structural weaknesses of the European economy, notably, slow productivity growth and a lack of contribution of information and communications technologies (ICT) to aggregate productivity growth. The Commission (2004b) also expressed concerns about the labour productivity slowdown in the Union and the widening gap with the US over 1995-2004, especially in high-technology sectors. The Commission (2004b) showed that growth in European high-technology sectors' productivity had been stronger than that of the overall economy of the EU, but lower than that of their US counterparts. The EU has experienced a slowdown in the productivity of its manufacturing industries and also of its high-technology sectors such as the digital industries. Moreover, Gorning and Schiersch (2014) find that the EU in general and the Euro Area in particular had a lower level of investment than the Organisation for Economic Co-operation and Development (OECD) average during 1999-2007. The Commission (2009a) warned that the 'potential GDP of the European Union could fall to a permanently lower trajectory', as 'the stock of equipment and infrastructure will decrease and become obsolete due to lower investment'.

\subsection{The European Commission acknowledges the crucial role of investment in economic growth}

The European Commission (2012b) acknowledges that investment is the driving force behind economic growth. It points to the need to keep up with the pace of technological progress in order for European firms to compete on a global scale: 'new investment is now urgently needed to stimulate economic recovery and bring innovation and new technologies back onto factory floors. If Europe does not keep up with investment in the adoption and diffusion of these technologies, its future competitiveness will be seriously compromised'. The Commission (2014a) insists on the need to increase investment in all sectors of the economy, especially in equipment, in order to improve the competitiveness of the EU. The Commission (2014b) reaffirms that investment to restore potential growth is a key policy priority and that the slow accumulation of fixed capital has hampered productivity and growth in the Union over 2007-2014. The Commission (2014c) also acknowledges that strong contraction of investment since 2008 is one of the primary reasons for the weakness of the recovery and that persistently low investment deteriorates potential growth.

\subsection{The Commission acknowledges that private investment can be harmed by weak profitability and that expected profitability influences investment}

The European Commission acknowledges that firms have to restore profitability to sustain investment. The Commission (2013b) indicates that 'the German case in the 2000s illustrates how restoration of profit margins may also have contributed to fostering investment and the possible link between profit margins and investment and innovation'. The Commission (2012c) acknowledged that sufficient profitability is required to finance investment: a 'reduction in the profitability of French firms, which reached historically low levels in 2011, weighs on their investment potential as well as their innovation capacity to the detriment of their non-cost competitiveness'. The Commission (2013b) indicates that 'the disappointing evolution of firms' profitability is particularly alarming because it may prevent firms from raising their investment in equipment, R\&D, marketing, brand'. The Commission also acknowledges that expected profitability drives investment forward. It relies upon Jorgenson (1963) who links investment to expected profitability and Tobin (1969) who notes that investment decisions depend on the expected value of future profits. Moreover, Herbet (2001) shows that restoring profit margins might have encouraged investment in the main developed countries in the 1990s. The Commission (2011a) acknowledges the link between investment 
decisions and expected profitability: 'Expectations of higher growth will contribute to restoring confidence and stability on financial markets. With improved prospects, businesses will start to invest again'. The Commission recognises both the need for profit margins to finance current investments and the need for sufficient expected returns to plan future investments.

\subsection{To support private investment, the Commission recommends fostering competition in order to tackle low profitability by reducing input costs}

In 2008, the European Commission expressed its commitment to a strong application of competition rules during the financial crisis, based on the view that 'competition enforcement strengthens the economy, even - perhaps particularly - in times of difficulty'. More recently, the Commission (2015b) indicated that competition has to be strengthened in order to encourage investment and efficient allocation of resources, through eased market entry and lower prices of services. For the Commission (2015c), a trade-off between competition and innovation is not empirically relevant, and competition succeeds 'in fostering productivity thanks to higher investments, better managerial organisation and innovation'.

In addition, the Commission (2013c) recommends to increase competition in the markets of intermediate inputs in order to raise industrial investment. Business services are essential inputs for the manufacturing sector and represent an important share of production costs. For the Commission, business services (including network industries) are sheltered from international competition while industrial sectors are exposed to foreign competitors. Opening sheltered business services to competition would then lower the cost of services used as inputs by exporting industry sectors.

The European Commission (2014d) affirms that increased competition intensity in these sheltered intermediary markets could contribute to lowering services' costs, hence improving competitiveness of the economy. It posits that 'low levels of competition in services translate into higher intermediary costs for firms and less innovative services', and as a result, 'further stimulating competition both in the product and services sectors would benefit exporting firms and contribute to their competitiveness'.

The Commission (2013c) posits that with lower factor costs, firms will restore their profit margins and their investment capacities. Lower production costs due to greater competition also 'strengthen entrepreneurs' expectations due to improved competitiveness that has translated into the recovery in investment'. The other priority to restore investment is to overcome firms' insufficient access of to external sources of funding, through the capital increase of the European Investment Bank, the allocation of structural funds and the implementation of the European Commission's Action Plan on Access to Finance for Small and Medium businesses (2011b). In the opinion of the Commission, firms with insufficient profit margins are supposed to overcome the shrinkage of their internal resources by turning to external (and notably public) funding sources to finance their investments.

\subsection{For the European Commission, dynamic efficiencies arise directly from static efficiency}

The European Commission promotes static competition, and aims to achieve static efficiency, a state where firms are not able to set their price above their marginal costs of production and make no profit. In this perfectly competitive frame, pricecost margins are eliminated, and all the effects of market power are removed. The European competition policy strives to eliminate the effects of market power at the level of upstream markets by lowering the intermediate inputs' and capital goods' prices, which in turn reduces production costs and leads to lower prices in the 
downstream markets. In addition, the Commission affirms that investment depends upon the wide availability of low-cost production factors, and expects investment to arise from intense static competition. The Commission considers that dynamic efficiencies arise directly from static efficiency. In the Commission's view, the resources needed to finance investment do not accrue from expected profit margins as fair return on investment, but from a greater availability of low-cost inputs. This greater availability stems from increased static competition in the intermediate input markets. Competition is either viewed as a steady state of static efficiency (where prices equal marginal costs) or an evolutionary process generating dynamic efficiencies. The Commission considers that investment arises exogenously from high levels of static competition. The Commission does not address the fact that the producers of intermediate inputs and capital goods might be discouraged to invest because of either insufficient funding resources or insufficient profit prospects.

\section{The differences between the European and the US doctrine on competition law and practice of competition policy}

This section describes the differences between the US and the European practices of competition policy, and explains how these differences can influence economic outcomes. The differences in the practices of competition policy relate to different doctrines on the objectives of competition law, the effects of market power on economic performance and the autonomy of dominant firms in setting their commercial and industrial strategies. The European competition policy strives to tackle all the effects of market power. By contrast, the US competition authorities, under the influence of the Chicago School, regard market power as a necessary condition to foster private investment, and do not consider the exercise of market power as inefficient. In practice, the US authorities intend to maintain the incentives of firms to invest in order to gain market power, whereas in the EU, the competition authorities consider that the effects of market power need to be eliminated.

\subsection{The European competition authorities monitor markets in order to ban market power effects}

The European competition authorities are empowered to monitor markets to ensure they reach their highest level of static competition. The European Commission (2009b) considers that a firm which is able to 'profitably increase prices above the competitive level for a significant period of time' does not 'face sufficiently effective competitive constraints and can thus generally be regarded as dominant'. The Commission considers that 'persistently high market shares may be indicative of the existence of barriers to entry and expansion'. Consequently, it considers that 'the stronger the dominant position, the higher the likelihood that conducts protecting that position leads to anticompetitive foreclosure'.

The practical elements of competition policy relating to concentrations are defined in the Guidelines on the assessment of mergers. In the Guidelines on the assessment of horizontal mergers, the European Commission (2004) explains that it must assess 'whether or not a concentration would significantly impede effective competition, in particular as a result of the creation or strengthening of a dominant position'. According to these Guidelines, the Commission must 'take into account any significant impediment to effective competition likely to be caused by a concentration. The creation or the strengthening of a dominant position is a primary form of such competitive harm'. Market shares are the indicator of static competition intensity: the European Commission (2004) indicates that 'the larger the market share, the more likely a firm is to possess market power. And the larger the addition of market share, the more likely it is that a merger will lead to a significant increase in market power'. The Commission notes that threats on 
effective competition do arise when 'the merged entity has a significant degree of market power (which does not necessarily amount to dominance) in at least one of the markets concerned'.

\subsection{The appraisal of market power by the European competition authorities might hamper the incentives of private firms to invest and innovate}

As explained by Fox (1997), the European Commission and the European Court of Justice 'readily presume dominance and increases in dominance without the kind of factual records that might be required in the United States.' The European competition law considers that a dominant firm is responsible for the competitive structure of the market. According to Marty and Pillot (2010), European competition law assigns the dominant firm a 'responsibility for competition'. The authors argue that the application of the doctrine of essential facilities to intangible assets like intellectual property has limited the strategic options of dominant firms. According to Lang (1979), in the case of United Brands in 1978, the European Court of Justice defined dominant position as the ability of a firm to prevent effective competition being maintained 'even if that power has not been exercised and so effective competition has not been ended'. For Marty and Pillot (2010), the 1979 Hoffman-Laroche judgment shows that the European competition authorities act to limit the market dominance of a firm because market power is regarded as a distortion of the competitive market structure. Therefore, competition authorities can sanction an abuse of dominant position on the basis of anticompetitive behaviour rather than on the basis of actual anticompetitive effects. Marty (2012) indicates that the 2003 decision of the Court of Justice (Michelin II) further confirmed that a dominant firm can be sanctioned because its behaviour might undermine competition, and not necessarily because of its actual anti-competitive effects. Marty (2012) also argues that, in the case of TeliaSonera's abuse of dominant position in 2011, the European Court of Justice reaffirmed the liability of the dominant firm to maintain 'effective' competition. Marty (2012) argues that the 2011 judgment provides further confirmation of the European Court of Justice's 2007 statement on France Telecom: 'showing an anticompetitive object and an anticompetitive effect may, in some cases, be one and the same thing. If it is shown that the object pursued by the conduct of an undertaking in a dominant position is to restrict competition, that conduct will also be liable to have such an effect'. If a dominant firm is shown to intend to distort competition, the European competition authorities can sanction it as an abuse of dominant position, even in the absence of anti-competitive effects.

\subsection{The influence of the Chicago School of antitrust has reoriented the US practice of competition law towards the promotion of economic efficiency}

The doctrine underlying the practice of competition law in the US experienced a major revision in the early 1970s, which, under the influence of the Chicago School of antitrust, led to a more flexible approach to market concentration and the behaviour of dominant firms. Prior to this revision, between 1940 and 1970, US competition law was influenced by the 'structuralist' approach developed by the Harvard School of economics, which considered that concentrated market structures led to anticompetitive behaviour and harmed economic welfare. During this period, the US competition authorities widely applied per se rules, according to which numerous practices of dominant firms where considered illegal per se, independently of their actual effects on the markets. This emphasis on market structures and per se rules led the US courts and competition agencies to broaden the range of conducts likely to be sanctioned, and to apply a strict antitrust policy. 
For Kovacic (2007), 'the courts defined the concept of wrongful behaviour so broadly that a wide range of conducts sufficed to create liability for dominant firms', and 'judicial decisions adopted an exceptionally expansive view of abuse'. The revision of the US doctrine on antitrust law which occurred by the early 1970s was inspired by the Chicago School's critical views regarding Per Se rules and their advocacy for economic efficiency 'as the exclusive basis for the design and application of antitrust rules', as noted by Kovacic (2007).

In addition, Marty (2010) mentions that in the opinion of the Chicago School, the aims of firms cannot be regarded as a proof of anticompetitive conduct, and that anticompetitive behaviour needs to be sanctioned on the basis of its actual effects on the market and on the basis of its impact on economic efficiency, rather than on the basis of its potential effects. For Piraino (2007), the approach of the Chicago School was adopted by the US courts and agencies in order to 'redress the harsh approach of the Harvard School, which often invalidated conduct that had the potential to enhance firms' efficiency and thereby benefit consumers'.

For Kovacic and Shapiro (2000), this adoption was motivated by the observations that US firms were losing competitiveness both on foreign markets and in the domestic market, and the idea that their declining performances might be induced by an excessive enforcement of antitrust policy. They explain that the Chicago School claimed that conduct such as vertical restraints were 'often benign or procompetitive' and that 'many phenomena, including industrial concentration, mergers, and contractual restraints' were sources of economic efficiency and should be allowed by the US courts and competition agencies. As a result, the US courts gave 'dominant firms considerable freedom to choose pricing, product development and promotional strategies'. For Kovacic (2007) the trend of US antitrust doctrine over the past thirty years 'has been to give dominant firms greater freedom to select pricing, product development, and distribution strategies', and 'the progression toward greater doctrinal permissiveness has not been unbroken'.

\subsection{The US doctrine on competition law regards market power as a source of economic performance and vertical integration as a potential source of efficiency}

Two key contributions of the Chicago School to the practice of US competition law relate to the appreciation of market power and the assessment of vertical relationships. The Chicago School considers that market power reflects the ability of firms to improve their performance and that sanctioning firms which acquired monopoly power might discourage them from competing intensively in order to provide consumers with higher quality products. According to Marty (2010), the US competition authorities have considered since the 1970s that the exploitation of a dominant position is lawful and justified because it allows invested capital to be recouped and is a fair return on a risky investment. Moreover, market power is an incentive for competitors to enter the market, and as such should not be sanctioned by the authorities. For Marty (2010), the Chicago School posits that a firm which acquire market power and extract an economic rent will increase social welfare in the short run. In the long run, its dominance will be challenged by new competitors, based on a self-correcting process inherent in the market.

As mentioned by Porter (2002), market power (prices above the marginal costs of production) allows for improvements in the quality of products, and 'high-value products provide the consumer with superior performance and features, and therefore justify higher prices'. Porter (2002) argues that higher prices should only be a concern for competition authorities if they are not justified by increased value for consumers, and claims that 'firm profitability is a good thing if it reflects truly superior products or significant advantages in process technology or operating efficiency', and that 'it is a bad thing if it occurs in the absence of a healthy rate of dynamic improvement'. Therefore, antitrust authorities that strive to 'limit short term 
price/cost margins or profitability' might underestimate the value brought to the consumer by dynamic competition and the related efficiency improvement. The measure of consumer welfare would then be affected by a downward bias and lead to decisions that are detrimental to consumers.

According to Riordan (2005) the Chicago School posits that vertical integration increases economic efficiency and rejects the structuralist view that it induces anticompetitive behaviour such as exclusionary practices and the leverage of monopoly power from one market to another'. Rey and Tirole (2007) explain that the Chicago School, led by the works of Bork (1978) and Posner (1976), considered that the 'leverage concept resulted from confusion about the exercise of market power'. Bork and Posner opposed the doctrine that vertical integration led to foreclosure. They claimed that a monopolist in the upstream market which can extract the entire monopoly profit from a competitive downstream market cannot obtain additional profits by extending its monopoly power. In the absence of efficiency gains, a vertical merger between an upstream monopolist and a downstream firm 'cannot increase the profitability of the merging firms'. There is only a single source of monopoly profit, which is unrelated to the extension of market power to the downstream market. The only possible rationale of vertical mergers relates to efficiency grounds (the possibility of reducing production costs) and not to conduct related to the foreclosure of competitors on the downstream market.

\subsection{The European and the US doctrine and the practice of competition agencies differ on the effects of market power and on the evidence of anticompetitive conduct}

Contrary to the US, the doctrine underlying the practice of competition law in Europe has not yet experienced an in-depth critical review. For Marty and Pillot (2009), the European competition authorities are still significantly influenced by the ordo-liberal School, or Freiburg School founded in the 1930s. This school of thought regards unrestricted competition as a founding principle of public action, and posits that the fundamental role of public authorities should be to preserve competition in itself. Dominance is viewed as a stable and permanent situation which cannot be tackled by the market and which requires public intervention to be eliminated. The primary role of competition policy is to promote and preserve the access of dominant firms' competitors to the market. Hence, the authorities' assessment of market structures should prevail over their assessment of the economic effects of dominant firms' behaviour. Marty (2010) asserts that the ordoliberal doctrine bans the concentration of economic power because such concentration prevents competitors' entry. The purpose of European authorities, under the ordo-liberal influence is to preserve the competitive market structure rather than to promote a market structure that maximises efficiency. For Marty (2010), the European Court of Justice's interpretation of the ordo-liberal doctrine entails a degree of similarity with the structuralist approach of the US authorities before 1970 as both can lead public authorities to attempt to prevent dominant positions per se. Marty (2010) highlights that in the structuralist as well as in the European Court of Justice's views, the public authorities' duty is to prevent all dominant firms' behaviour that could potentially foreclose competitors and limit their ability to grow.

For Cooper et al. (2005), 'Ordoliberalism tends to focus on the form, rather than the competitive effect of business relationships'. The European doctrine on competition law regards market power as self-perpetuating, and regards vertical relationships as prone to anticompetitive conduct. For example, vertical restraints such as exclusive dealing and exclusive supply contracts 'necessarily foreclose competitors from contracting opportunities, and thus may be seen as perpetuating dominance'. In the context of persistent ordo-liberal influence, the European doctrine on vertical restrictions has recently shifted to an approach closer to the post-Chicago analysis, 
as argued by Marty (2007) and Kovacic (2008a). The post-Chicago analysis, which developed in the early 1990s, has criticised the Chicago School's view that vertical mergers are pro-competitive and that vertical integration generates efficiencies.

According to Riordan and Salop (1995) the 'post-Chicago' approach considers that vertical mergers can have anticompetitive effects by 'creating, enhancing, or facilitating the exercise of market power', and that vertical mergers 'can be motivated by monopoly power, economic efficiency concerns or both'. The postChicago analysis on vertical integration differs from the Chicago School's view because it considers that the upstream monopolist has a rationale for exercising its market power in the downstream market, otherwise downstream competition may limit its ability to exercise its upstream market power. Therefore, contrary to the Chicago School's view, the rationale for a vertical merger might not always be related to the prospect of increasing efficiency.

The European Commission (2015d) agrees with the view that dominance in the upstream market is likely to extend to the downstream market, reducing the incentives of downstream firms to innovate because 'the rents which downstream firms can expect from efficiency improvements are likely to be partially captured by the suppliers of the intermediate inputs upstream' and that 'a lack of competition in the upstream market can generate entry barriers limiting competition downstream if access to downstream markets requires using intermediate inputs produced upstream'.

For Kovacic (2008b), the European competition authorities have tended to 'create a wider zone of liability for dominant firms than the decisions of the US courts' and that 'courts and enforcement agencies commit greater errors by intervening too much rather than too little. This perspective does not appear in EU jurisprudence or in speeches by EU enforcement officials'. This quote implies that, in the US perspective, overly restrictive antitrust enforcement would likely harm the economy because it could prevent efficiency gains from occurring. By contrast, in the European perspective, overly restrictive enforcement is to be preferred to an overly flexible approach because it is better to prevent anticompetitive behaviour from arising than to allow for potential efficiency gains to occur.

In its Guidelines on Vertical Restraints, the Commission (2010b) outlines that the softening of competition (along with foreclosure and collusion) at the wholesale level (in the upstream market) harms consumers "by increasing the wholesale prices of the products, limiting the choice of products, lowering their quality or reducing the level of product innovation'. It might also harm consumers at the retail level 'by increasing the retail prices of the products, limiting the choice of priceservice combinations and distribution formats, lowering the availability and quality of retail services and reducing the level of innovation of distribution'. By contrast, according to Marty and Pillot (2012), the US Supreme Court stated that for industries where there is an ex-ante regulation, such as network industries, the enforcement of antitrust to tackle market power of an upstream firm is not necessary: 'when there exists a regulatory structure designed to deter and remedy anticompetitive harm, the additional benefit to competition provided by antitrust enforcement will tend to be small, and it will be less plausible that the antitrust laws contemplate such additional scrutiny'.

This difference in antitrust enforcement relates to the different doctrines adopted in the US and in the EU, where the post-Chicago approach recommends eliminating the effects of market power in upstream markets in order to prevent dominance being exercised in downstream markets, advocating a strict control of vertical restraints and vertical mergers. By contrast, the Chicago School does not recommend such strict antitrust enforcement, because market power is not viewed as a source of inefficiency and because vertical integration is viewed as a source of efficiency gains. 


\subsection{Market power (mark-ups on competitive price) is not regarded as economically inefficient by the US competition authorities}

For Shapiro (2011), the US antitrust law has 'understood for a very long time that the market power resulting from successful innovation is an important and inevitable part of the competitive process', and that the US merger policy does not strive for perfectly competitive market structures. Shapiro (2011) does not find any conflict between 'competition policy principles and the Schumpeterian observation that successful innovators often are able to price well above marginal cost and often gain substantial market shares.'

According to Marty and Pillot (2009), a core principle of US competition policy is the preservation of firms' incentives to acquire market dominance. According to the US competition law, the exercise of market power is in the interest of the global economy. The authors argue that, contrary to the European approach, the US competition law does not strive to limit the strategic autonomy of the dominant firm. It considers that the purpose of competition law is not to affirm the specific responsibility of the dominant firm towards its competitors and the market structure. In this view, the dominant firm is not responsible for maintaining its competitors on the market. The dominant position is therefore a fair return on the capital invested. Market dominance provides incentives to invest in order to challenge the market power of the dominant firm.

As noted by Newman (2014), the Antitrust Division of the US Department of Justice acknowledges that the social cost of false positive (i.e. wrongly sanctioning nonanticompetitive behaviour) is higher than the false negative (i.e. failing to condemn real anticompetitive behaviour). This practice is justified by the belief that markets can efficiently correct 'judicially unchecked anticompetitive behaviour' while they are not able to 'correct a judicial ruling that wrongly condemns benign behaviour'. In Verizon vs. Trinko (2004), the US Supreme Court stated that 'the charging of monopoly prices was not a breach of the Sherman Act' unless 'it is accompanied by an element of anticompetitive conduct', and that forcing the dominant firm to share the source of its competitive advantage with its competitors contradicts the purpose of antitrust policy. In the case of Blue Cross (1995), the Court of Appeals stated that a lawful monopolist "may charge any price that he wants, for the antitrust laws are not a price-control statue or a public-utility or a common-carrier rateregulation statue'. The case of Microsoft (2004) evidenced the differences between the US and the EU in the appraisal of market power. The $€ 497$ million fine imposed by the European Commission on Microsoft for abusing its dominant position has been criticised by US competition law practitioners and theorists alike. E.-M. Fox (2006) claimed that the decision limited the strategic autonomy of the dominant firm, and reflected 'Europe's principle of special responsibility of the dominant firm and the prohibition of using leverage and power to obtain advantages over rivals. These principles overshadow any freedom of the dominant firm to choose with whom and how to deal'. Moreover, T.O. Barnett (2007) opposed the European Commission's decision, stating that 'in the absence of demonstrable consumer harm, all firms, including dominant firms, are encouraged to compete vigorously'. Barnett (2007) outlines that the US competition authorities favour the strategic autonomy of dominant firms over maintaining competitive market structures: 'US courts recognize the potential benefits to consumers when a firm, including a dominant firm, makes unilateral business decisions, for example to add features to its popular products or license its intellectual property to rivals, or to refuse to do so.' 


\subsection{The purpose of US competition law is to promote incentives to gain market power, whereas the purpose of the European competition law is to maintain 'effective' competition}

The US competition law does not ban the effects of market power and concentrated market structures as long as they do not result from unfair anticompetitive behaviour. Market power is not viewed as a barrier to entry as long as it results from a firm's efforts to acquire and develop a competitive edge. The European competition authorities ban the effects of market power on the basis of the ordo-liberal doctrine. The influence of the post-Chicago approach induces European authorities to prevent market power leverage (i.e. the extension of upstream market power to the downstream market). The European competition authorities prevent dominant firms from deriving the full return on their investments because they consider that exercising market power is economically inefficient. The appraisal of market power by the European competition authorities might as a result hamper private incentives to invest. The European practice of competition law tends to limit the strategic autonomy of the dominant firms, because its objective is to promote the access of its competitors to the market rather than to maximise efficiency.

\section{The endogenous nature of innovation and its relationship with competition}

This third section builds on recent results from theoretical and empirical economics which call the European Commission's doctrine into question. These results explain why a systematic increase in the level of static competition might discourage investment. Technological progress only occurs provided that firms respond to incentives to invest in new technologies and products, and these incentives depend on existing and expected levels of competition. There is a tradeoff between the level of competition and endogenous innovation, so that dynamic efficiencies hardly arise from static efficiency, especially in industries with high innovation rates.

\subsection{Technological progress is created by economic agents who respond to market incentives}

In the neoclassical framework, technological change is exogenous to the market. In the seminal model of Robert Solow (1956), technological change is a public input provided exogenously to the market. It is a non-rival and non-excludable good. Solow (1957) posits that growth is sustained in the long run by technological change, which only depends on the evolution of time. Paul Romer (1986) renders technological change endogenous: it is the outcome of private investment. Longterm growth is sustained by the accumulation of knowledge, a process which occurs through the investment of private firms. Romer (1990) posits that technological change results in large part from 'intentional actions taken by people who respond to market incentives'. Technological change occurs only if 'selfinterested individuals' can capture a sufficient benefit from their investment in the improvement of technology, whose benefits are 'at least partially excludable'. Market incentives are crucial to technological progress because they drive the transformation of new knowledge into goods with practical value. Romer (1990) explains that 'initial understanding of electromagnetism arose from research conducted in academic institutions, but magnetic tape and home videocassette recorders resulted from attempts by private firms to earn a profit'. To increase productivity, firms have to invest in capital goods which incorporate technological innovations. The driver of this investment is the prospect of earning a profit. This assertion implies that unless there is private investment in fixed assets, available innovations per se will not have any effect on productivity. 


\subsection{Firms invest in the production of technological innovation provided there exist sufficient expected reward, hence a sufficiently concentrated market structure}

For Romer (1990), the creation of innovations is equivalent to incurring a fixed cost, and once they are produced, they can be used at no additional cost. Technological innovations are partially excludable and non-rival goods. The costs incurred to produce new goods are recovered provided they are sold at a price higher than their marginal cost of production. Therefore, endogenous innovation cannot occur under price-taking competition. The investment in capital goods that embody innovations depends on the ability of investors to recover their investment. A certain degree of market power is needed for investments to occur, thus for technological progress to spread through society. Romer (1994) posits that endogenous growth theory has allowed economists to take account of two evident facts on innovation: the endogenous nature of technological progress and the existence of market power and monopoly rents stemming from innovations. As noted by Shapiro (2011), 'we would not expect to see atomistic market structures in industries that have experienced significant technological progress, and we may see high levels of concentration in markets that have recently experienced significant innovation'. A notable policy implication of endogenous growth models is that imperfect competition is needed to support the accumulation of knowledge through discoveries and the spread of technological progress through investment in capital goods. Firms are incentivised to invest provided they expect temporary monopoly rents in the form of mark-ups over competitive prices or higher market shares. For these reasons, a policy only aiming to increase static efficiency would hardly succeed in providing firms with incentives to invest in new technologies and products.

\subsection{The relationship between competition and investment is non-linear in empirical literature}

'Are we so sure that competition always favours innovation in developed countries?' With this question, Aghion and Griffith (2005) underline the uncertain relationship between competition and economic growth. There is no clear evidence that greater competition necessarily fosters innovation. The relationship between competition and growth has remained an open question so far. To the question 'can one turn to economists for clear and definite views on this debate?', the authors answer 'no' and claim 'it is fair to say that economists still have a limited and sometimes contradictory understanding of (competition's) economic effects and, in particular, of the relationship between competition and growth'.

Empirical studies on cross-industry panels provide evidence of a non-linear relationship between competition and innovation. Aghion et al. (2005) show that the Schumpeterian effect dominates the escape from competition effect once competition exceeds its optimal level. They provide empirical evidence of an inverted U-shaped relationship between competition and innovation. Instead of indefinitely increasing with competition, the rate of technological progress decreases after competition exceeds an optimal threshold. Above this optimal threshold, competition hinders the reward from investment. Competition reduces the incentives for firms to invest in innovation 'by reducing the rents that can be captured by a follower who succeeds in catching up with its rival by innovating'. An increase in the level of competition can foster innovation when firms have a same level of technology, according to the escape from competition effect. However, when the level of technology is unevenly distributed across firms, an increase in competition intensity will discourage laggard firms from investing in order to catch up with the leaders because it reduces the post-innovation rents. Following Aghion et al. (2005), Askenazy et al. (2008) evidence an inverted U-shape relationship between competition and R\&D investment, finding that competition has weak 
effects on investment in the production of innovations when their costs are relatively high. In sectors where innovation becomes too costly, policies to increase competition will unlikely induce firms to invest. This suggests 'modulating competitive policies according to the state of the industry'.

\subsection{Recent results in microeconomics invalidate the single monotonic increasing relationship between competition and innovation}

Theoretical microeconomics provides insights that the relationship between competition and investment is ambiguous and depends largely on models and assumptions. For Belleflamme and Vergari (2010), 'an intermediate form of competition may provide a higher incentive to innovate than the traditional polar cases (either monopoly or perfect competition)'. They show that optimal level of competition varies across sectors, in accordance with their specific characteristics, and find that 'different industries are affected in qualitatively different ways by an increase in competition'. The profit incentive that motivates investment is maximised 'depending on the characteristics of the industry of interest'. The profit incentives are maximised either 'by a competitive firm (Arrow's claim), by a monopoly (Schumpeter's claim) or by an intermediate form of competition'. Schmutzler (2013) provides a general theoretical framework to analyse the effects of increasing competition on investment, and concludes that these effects are ambiguous and vary largely according to the initial levels of efficiency (the marginal costs) and the initial level of competition. The theoretical framework accounts for all types of relationships. Sacco and Schmutzler (2011) show that the relationship between competition and R\&D investment depends on the theoretical framework. However, ongoing microeconomic research tends to show that the non-monotonic relationship between competition and investment in technology might be related to its innovation intensity. Houngbonon and Jeanjean (2014) develop a theoretical model of the relationship between competition and investment in technology, where technological progress is captured by the impact of innovation on the marginal cost of production. They show that the inverted U-shape relationship between the level of competition intensity and the investment in technology is more likely to occur when the rate of technological progress is high. Moreover, the higher the innovation potential, the higher the level of price-cost margin which maximises investment in innovation.

\subsection{Capital-intensive industries with high rate of innovation require a concentrated market structure (i.e. the existence of market power) to sustain their investment effort}

A recent literature has explored the link between market concentration, the level of competition and the rate of innovation. It suggests that too restrictive merger policies can hinder the rate of innovation. Ivaldi \& McCullough (2010) examine the welfare effects of mergers that have occurred in the US railroad freight market, where consolidations have increased both market power and the efficiency of service providers. During 1978-2006, mergers reduced the number of providers, increased market concentration and brought efficiency gains. Productivity and efficiency gains have been largely transferred to consumers through lower prices and higher volumes. In the long run, 'despite a dramatic degree of consolidation in the industry', the initial decline in consumer welfare has been followed by a sharp continuous increase. Mergers have not harmed social welfare and have brought large efficiency gains.

For Tilford (2008), in high-technology sectors like pharmaceuticals or ICT, large market shares do not always mean less competition as few firms often bear the bulk of investment costs. Market power is often temporary because firms are competing through investments in technology, which sustains a permanent process 
of transition between dominant technologies. Tilford (2008) argues that if firms 'are forced to share their intellectual property with competitors, or prevented from controlling the price at which their products and services are sold, there is a risk that they will innovate less'. For Shapiro (2011), 'a highly successful innovator may come to dominate a market, in which case observing a high level of ex post concentration would hardly imply a lack of ex ante competition, or a lack of innovation'. Shapiro (2011) indicates that atomistic market structures should not be expected in industries where significant technological progress has occurred. On the contrary, highly concentrated market structures should normally occur in industries that have experienced significant innovations. Gans (2015) outlines that a permissive antitrust policy which makes mergers more likely to occur can promote competition in industries which have high innovation rate and where the returns on investment in technology are short-lived. The prospect of merging with highly innovative firms encourages entry and increases competition in innovation. Gans (2015) suggests that merger policies can have long-lasting effects on competition and the rate of innovation. Indeed, under a stronger antitrust enforcement, more potential mergers are likely to be blocked, which causes firms that 'might otherwise have stayed in longer to find a merger partner' to exit the industry. The market is thus deprived of R\&D investment and innovations that those firms would have produced.

This effect is investigated empirically by Igami and Uetake (2015) who show that the strengthening of merger policy in a highly innovative industry would not necessarily result in higher competition, innovation and welfare. They study the hard-disk drive global industry between 1976 and 2014, and provide evidence that a tighter merger policy can decrease firms' value and increase the number of exits by liquidation. When the opportunities to merge with an innovative firm decrease, firms expect that productivity improvements and market power will decrease and thus choose to exit. A high rate of merger blocking in highly innovative industries could hinder competition and innovation by discouraging entry and encouraging exit.

According to the OECD (2012), 'there can be sectors or industries where innovation is greater when firms have the possibility to acquire a monopolist position, at least temporarily, and thus charge a price which is above marginal cost during such a period'. The OECD (2012) explains that in sectors with high rates of innovation such as the pharmaceutical industry, competition occurs mainly through 'races to innovate' rather than through price setting, and 'during the period of patent protection, firms are usually able to charge a supra-competitive price, which allows them to recoup the high costs incurred during the research and development stages'. Dynamic efficiencies, which are related to 'the ability of a firm and its incentives to introduce new products or processes of production (or to improve existing ones)', will hardly arise from a market where static efficiency is achieved, because in such market, prices would equal marginal costs of production.

The OECD (2007) concludes that for this reason, the 'textbook perfect competition may be inconsistent with dynamic efficiencies'. The capacity to set prices above the marginal costs of production is necessary for innovation to occur. For this reason, investment in new technologies and new products would not arise in markets where static efficiency is achieved. Overall, the results presented in this subsection support the view that investments in technologies and capital goods that incorporate technologies are likely to be discouraged when static competition is too high, and need either concentrated market structure or market power to occur. 


\subsection{Cross-country differences in growth rates stem from differences in the levels of investment in fixed assets which incorporate technologies}

From Romer (1990), it appears that productivity gains stem from the diffusion of capital goods which have incorporated new technologies through fixed assets investment. Cross-country differences in the rates of innovation diffusion through investment should then explain a large part of the cross-country differences in rates of productivity growth. Comin and Mestieri (2010) provide evidence that the diffusion of new technologies has a major role in explaining long-run international differences in per-capita income, and that these differences are mostly due to the cross-country differences in investment in the fixed assets that incorporate the new technologies. The authors study the contribution of technological change to the growth of aggregate productivity of 166 countries over the period 1820-2003. They posit that the adoption of new technologies by a country has two distinct components: the extensive margin of adoption, which captures the adoption lag, (how long it takes to adopt a new technology) and the intensive margin of adoption, which measures how many intermediary goods embodying the new technology are being used to produce the final goods. They estimate that the international differences in the adoption of technologies explain nearly 70 percent of the differences in countries' per-capita income in the long run, and that the larger part of these differences can be attributed to differences in intensive margins of adoption, hence, in investment in intermediary goods that incorporate the new technologies.

Van Ark et al. (2008) find that the contribution of ICT capital to the growth of aggregate labour productivity has been relatively higher than the contribution of labour and of non-ICT capital in either the EU (EU-10) or the US over 1980-2004. Moreover, the growth of labour productivity has slowed down since 1995 in the EU while it has significantly accelerated in the US, due to both higher levels of ICT investment and a faster diffusion of ICT assets in the market services sector. The authors underline that the main driving force of the growth of labour productivity in the US in the mid-1990s related to both a rise in the productivity of industries producing ICT equipment and a capital-deepening effect fuelled by investment in ICT assets by the other sectors of the economy. Van Welsum et al. (2013) confirm that the weaker labour productivity growth of the EU compared to the US has persisted after the mid-2000s and can be largely explained by a weaker impact of investment in ICT capital goods on labour and total factor productivity. The differences in aggregate labour productivity growth between the EU and the US are significantly related to differences in the levels of aggregate investment in ICT capital goods. These results show that the level of aggregate investment in fixed assets which incorporate digital technologies has a major impact on the rate of productivity growth of a country, and a large share of cross-country differences in the rates of productivity growth can be attributed to cross-country differences in the levels of such investment.

\section{The European and US doctrines in light of recent economic findings on competition and innovation}

Evidence presented in the three preceding sections outlines that the US competition policy appear more consistent with the recent advances in theoretical and empirical economics than the European doctrine and practice. The European competition authorities still regard market power as a source of inefficiency and consider that the effects of market power have to be removed because they harm the competitive process. This can lead the European authorities to sanction strategic behaviours that are in reality pro-competitive, hence taking the risk of depriving the economy from potential additional efficiency gains. 
European competition policy rules out any possible trade-off between static efficiency and dynamic efficiencies. It strives to enhance static competition and to remove the effects of market power. The views of the European competition authorities on market power are still strongly influenced by the 'ordo-liberal' doctrine, which considers that the main purpose of economic policy is to promote entry and to limit the possibility of the dominant firm to exert its market power.

However, literature examined in the third section shows that investment in innovation will not arise from a market where static efficiency is achieved. Firms which cannot set prices above marginal costs will have neither the incentives nor the capabilities to invest in technology. A market where the level of static competition exceeds its optimal threshold will tend to decrease the rate of endogenous innovation. The European competition authorities, under the influence of the post-Chicago synthesis, tend to prevent efficiencies due to vertical integration from occurring. Indeed, they consider that vertical restraints are potentially anticompetitive and that vertical integration is more likely to allow the exercise of upstream market power than to generate efficiencies.

By contrast, the U.S courts and competition agencies work to preserve market power and consider that upstream market power unlikely extends itself to the downstream markets. They consider that market power is a necessary incentive for firms to engage in risky investment and that supra-competitive profit is a normal return on investment. The US courts (since the adoption of the Chicago School's views) ceased to consider competitive market structure as an objective per se, and focused on the promotion of efficiency. The higher rates of productivity growth achieved by the US during the last twenty years can to a large extent be attributed to higher levels of investment in ICT during this period. On the basis of the analysis of the U.S competition principles provided in the second section, it can be inferred that these levels of investment could have been favoured by the US doctrine on competition law.

Under US competition law, the dominant firm has more strategic autonomy and the search for market power is promoted rather than discouraged by the US courts. In particular, the higher level of investment of ICT industries (which are network industries under an ex-ante regulation) in the US appears to be at least in part favoured by the doctrine of US competition agencies. Indeed, the US competition authorities promote market power, do not ban concentrated market structure per se, and are sceptical of the incentives of integrated firms to leverage market power.

\section{Conclusion}

The European Commission's economic policy, which regards competition policy as the main engine of economic growth, builds upon its doctrine on competition law. This doctrine is influenced by a structuralist approach of market power and a postChicagoan view on the assessment of vertical restraints. These approaches lead European authorities to favour non-concentrated market structures independently of economic efficiency. Besides, European policy strives to increase the level of static competition (i.e. lowering prices down to the marginal costs) because it considers that dynamic efficiencies (investment in technology) arise from static efficiency.

This policy favours static over dynamic competition, and ignores the trade-off between static and dynamic efficiencies. The European economic policy tends to limit the incentives and capacities to invest in new technologies and in fixed assets that incorporate those technologies. Such a policy hampers dynamic efficiencies by impeding expected profit margins which are needed to sustain current and future investments. On the contrary, US doctrine, under the influence of the Chicago School, has led US authorities to favour economic performance over maintaining non-concentrated market structure, to acknowledge market power has a legitimate 
incentive and investment reward, and to avoid enforcing robust antitrust in regulated industries where vertical integration generates efficiencies. This doctrine might have led to a competition policy more likely to sustain investment in the most productive and technologically advanced industries. Indeed, the higher levels of US ICT investment have contributed to higher growth, and the gap with the EU has begun to widen when ICT were being heavily adopted through high investment efforts. In light of these results, the European Commission's economic doctrine needs a review in order to restore profitability, technological leadership and growth.

\section{References}

Aghion, Philippe and Rachel Griffith (2005) Competition and Growth. Reconciling Theory and Evidence. Cambridge, Ma: MIT Press, 2005.

Aghion, Philippe, Nick Bloom, Richard Blundell, Rachel Griffith and Peter Howitt (2005) 'Competition and Innovation: an Inverted-U Relationship', Quarterly Journal of Economics 120(2): 701-728.

Askenazy, Philippe, Christophe Cahn and Delphine Irac (2008) 'Competition, R\&D, and the Cost of Innovation', Banque de France, Notes d'Etudes et de Recherche, NER - R Nº197.

Barnett, Thomas O. (2007) 'Issue Statement on European Microsoft Decision', US Department of Justice, Antitrust Division. Press Release 202-514-2007, September 17 th.

Belleflamme, Paul and Cecilia Vergari (2010) 'Incentives to innovate in oligopolies', The Manchester School 79(1): 6-28.

Bork Robert, H. (1978) The Antitrust Paradox: a Policy at War with itself, Free Press, New York.

Cette, Gilbert (2015) 'Which Role for ICTs as a Productivity Driver Over the Last Years and the Next Future?', Digiworld Economic Journal 100 , 65-83.

Comin, Diego and Marti Mestieri (2010) 'The Intensive Margin of Technology Adoption', Harvard Business School Working Paper 11-026.

Cooper, James C., Luke M.Froeb, Daniel P. O'Brien, and Michael G. Vitta (2005) 'A comparative study of United States and European Union approaches to vertical policy' George Mason Law Review (13)2: 289-308.

Fox, Eleanor M. (1997) 'US and EU Competition Law: a Comparison', in E.M Graham \& D.J. Richardson D.J. (eds), Global Competition Policy. Washington, DC: Peterson Institute for International Economics pp. 339-354.

Fox, Eleanor M. (2006) 'Abuse of Dominant Position: The Americanization of European Competition Law: the Critical Role of Perspective: Comment', in $\mathrm{H}$. Ullich (eds), The Evolution of European Competition Law: whose Regulation, which Competition?, Cheltenham: Edward Elgar Publishing, pp. 233-237.

Gans, Joshua, S. (2015) 'Mergers and disruptive innovation.' Hogan Levels Global Media and Communications Quarterly Autumn 2015.

Gorning, Martin and Alexander Schniersch (2014) 'Weak Investment in the EU: A Long-Term Cross-Sectoral Phenomenon', DIW Economic Bulletin S.23-30.

Herbet, Jean-Baptiste (2001) 'Peut-on expliquer l'investissement à partir de ses déterminants traditionnels au cours de la décennie 90 ?', Économie et statistique $n^{\circ}$ 341-342, 85-106.

Houngbonon, Georges V. and Francois Jeanjean, (2014) 'Is there a level of competition intensity that maximises investment in the mobile telecommunications industry?'. Paper presented at the 25th European Regional Conference of the 
International Telecommunications Society (ITS), Brussels, Belgium, 22-25 June 2014.

Igami, Mitsuru, and Kosuke Uetake, (2015) 'Mergers, Innovation and Entry-Exit Dynamics: The Consolidation of the Hard Disk Drive Industry' (1996-2015), Mimeo, Yale University.

Ivaldi, Marc and Gerard McCullough (2010) 'Welfare Tradeoffs in US Rail Mergers', Working Paper $n^{\circ} 344$, IDEI.

Jorgenson, Dale W. (1963) 'Capital Theory and Investment Behaviour', American Economic Review 53(2):247-259.

Kovacic, William E. (2007) 'The intellectual DNA of modern US competition law for dominant firm conduct: the Chicago/Harvard double helix', Columbia Business Law Review 2007 (1): 1-80.

Kovacic, William E. (2008a) 'Competition policy in the European Union and the United States: convergence or divergence in the future treatment of dominant firms?', Competition Law International October 2008, 8-18.

Kovacic, William E. (2008b) 'Competition Policy in the European Union and the United States: Convergence or Divergence?' Bates White Fifth Annual Antitrust Conference Washington, D.C. June 2, 2008

Kovacic, William E. and Carl Shapiro (2000) 'Antitrust Policy: A Century of Economic and Legal Thinking', Journal of Economic Perspectives14(1): 43-60.

Landes, William M. and Richard A. Posner, (1981) 'Market Power in Antitrust Cases', Harvard Law Review 94 (5): 937-996.

Lang, John T. (1979) 'Some Aspects of Abuse of Dominant Positions in European Community Antitrust Law', Fordham International Law Journal 3(1): Article 1.

Marty, Frédéric (2007) 'Le contrôle des concentrations en Europe et aux EtatsUnis. Critères économiques et sécurité juridique', Revue de l'OFCE 2007/1,100.

Marty, Frédéric (2010) 'Politiques européennes de concurrence et économie sociale de marché', Document de travail de l'OFCE No 2010-30.

Marty, Frédéric (2012) 'De la notion de responsabilité particulière de l'opérateur dominant dans la politique de concurrence européenne : Quelles conséquences sur les libertés économiques ?', in L. Potvin-Solis \& H. Ueda (eds), Économie de marché, droits et libertés et valeurs communes en Europe et en Asie. Editions de la Chaire Jean Monnet Université de Lorraine, pp. 181-204.

Marty, Frédéric and Pillot Julien (2009) 'Les politiques de concurrence européenne et américaine face aux remises de fidélité accordées par une entreprise dominante : L'affaire Intel', Document de travail de l'OFCE No 2009-26.

Marty, Frédéric and Pillot Julien (2010) 'Divergences transatlantiques en matière d'application de la théorie des facilités essentielles aux actifs immatériels', Revue d'économie industrielle 2010/1 (No 129-130), 277-300.

Marty, Frédéric and Pillot Julien (2012) 'Pratiques de boycott ou refus d'accès à une facilité essentielle'. De Terminal Railroad à I'IRM d'Arcachon'. Revue Lamy de la concurrence 2011, 17-25.

Newman, John M. (2014) 'Antitrust in Zero-Price Markets: Foundations', University of Pennsylvania Law Review 164, 149-206

OECD (2007) 'Dynamic Efficiencies in Merger Analysis', OECD Policy Roundtables. Directorate for Financial and Enterprise Affairs - Competition Committee. 
OECD (2012) 'The Role of Efficiency Claims in Antitrust Proceedings', OECD Policy Roundtables. Directorate for Financial and Enterprise Affairs - Competition Committee.

Piraino, Thomas A. (2007) 'Reconciling the Harvard and Chicago Schools: A new Antitrust Approach for the 21st Century', Indiana Law Journal 82(2): 345-409.

Porter, Michael, E. (2002) 'Competition and Antitrust: A Productivity-Based Approach', Mimeo, Harvard Business School.

Posner Richard A. (1976) Antitrust Law: An Economic Perspective, Chicago: University of Chicago Press,.

Rey, Patrick and Jean Tirole (2007) 'A Primer on Foreclosure', in Mark Armstrong and Rob Porter (eds), Handbook of Industrial Organization 3, Oxford:North Holland, pp. 2145-2215.

Riordan, Michael, R. (2005) 'Competitive Effects of Vertical Integration', Discussion Paper No.0506-11, Department of Economics, Columbia University.

Riordan, Michael H. and Steven C. Salop (1995), 'Evaluating Vertical Mergers: A Post-Chicago Approach', Antitrust Law Journal 63, 513-568.

Romer, Paul M. (1986) 'Increasing Returns and Long-Run Growth', The Journal of Political Economy 94(5):1002-1037.

Romer, Paul M. (1990) 'Endogenous Technological Change', The Journal of Political Economy 98(5): 71-102.

Romer, Paul M. (1994) 'The Origins of Endogenous Growth', The Journal of Economic Perspectives 8(1): 3-22.

Sacco, Dario, \& Armin Schmutzler, (2011) 'Is there a U-shaped relation between competition and investment?' International Journal of Industrial Organization 29(1): 65-73.

Shapiro, Carl (2011) 'Competition and Innovation: Did Arrow Hit the Bull's Eye?', in J. Lerner \& S. Stern (eds), The Rate and Direction of Inventive Activity Revisited. NBER, pp. 361-404.

Solow, Robert M. (1956) "A Contribution to the Theory of Economic Growth', The Quarterly Journal of Economics 70(1): 65-94.

Solow, Robert M. (1957) 'Technical Change and the Aggregate Production Function', The Review of Economics and Statistics 39(3): 312-320.

Schmutzler, Armin (2013) 'Competition and investment - A unified approach.' International Journal of Industrial Organization 31(5): 477-487.

Tilford, Simon (2008) 'Is EU competition policy an obstacle to innovation and growth? Centre for European Reform essays.

Tobin, James (1969) 'A general equilibrium approach to monetary theory', Journal of Money, Credit and Banking 1(1): 15-29.

Van Ark, Bart, Mary O' Mahoney, and Marcel P. Timmer (2008) 'The Productivity Gap between Europe and the United States: Trends and Causes', Journal of Economic Perspectives 22(1): 25-44.

Van Ark, Bart and Abdul Erumban (2015) 'Productivity Brief 2015. Global Productivity Stuck in the Slow Lane with No Signs of Recovery in Sight', The Conference Board Productivity Brief 2015, The Conference Board.

Van Welsum, Desiré, Overmeer, Willem and van Ark, Bart (2013) 'Unlocking the ICT growth potential in Europe: Enabling people and businesses', The Conference Board, Report for the European Commission GD Communications Networks, Content \& technology. 


\section{Documents from the European Commission and European Parliament}

European Commission (2004a). A pro-active Competition Policy for a Competitive Europe. Brussels, 20.4.2004, COM(2004) 293

http://eur-

lex.europa.eu/LexUriServ/LexUriServ.do?uri=COM:2004:0293:FIN:EN:PDF

European Commission (2004b). Fostering structural change: an industrial policy for an enlarged Europe. Brussels, 20.4.2004, COM(2004) 274 final.

http://eur-

lex.europa.eu/LexUriServ/LexUriServ.do?uri=COM:2004:0274:FIN:en:PDF

European Commission (2004). Guidelines on the assessment of horizontal mergers under the Council Regulation on the control of concentrations between undertakings. Official journal of the European Union. (2004/C 31/03).

http://eur-

lex.europa.eu/LexUriServ/LexUriServ.do?uri=OJ:C:2004:031:0005:0018:en:PDF

European Commission (2008). Press Release SPEECH/08/658. 'Achieving selfsustaining competition in telecommunications'. Neelie Kroes, 9th Annual ECTA Regulatory Conference. Brussels, 27 November 2008.

http://europa.eu/rapid/press-release_SPEECH-08-658_en.htm

European Commission (2008). Guidelines on the assessment of non-horizontal mergers under the Council Regulation on the control of concentrations between undertakings. Official journal of the European Union (2008/C 265/07).

http://eur-

lex.europa.eu/LexUriServ/LexUriServ.do?uri=OJ:C:2008:265:0006:0025:en:PDF

European Commission (2009a). Economic Crisis in Europe: Causes, Consequences and Responses. Directorate-General for Economic and Financial Affairs 7/2009.

http://ec.europa.eu/economy_finance/publications/publication15887_en.pdf

European Commission (2009b). Guidance on the Commission's enforcement priorities in applying Article 82 of the EC treaty to abusive exclusionary conduct by dominant undertakings. Official journal of the European Union (2009/C 45/02).

http://eur-

lex.europa.eu/LexUriServ/LexUriServ.do?uri=OJ:C:2009:045:0007:0020:EN:PDF

European Commission (2010a). 'EUROPE 2020. A European strategy for smart, sustainable and inclusive growth'. http://ec.europa.eu/eu2020/pdf/COMPLET\%20EN\%20BARROSO $\% 20 \% 20 \% 20007$ \%20-\%20Europe\%202020\%20-\%20EN\%20version.pdf

European Commission (2010b). Guidelines on Vertical Restraints.

http://ec.europa.eu/competition/antitrust/legislation/guidelines_vertical_en.pdf

European Commission (2011a). ANNEX to the Annual Growth Survey 2012.

http://ec.europa.eu/archives/commission_2010-

2014/president/news/documents/pdf/annex_2_en.pdf

European Commission (2011b). An action plan to improve access to finance for SMEs. Brussels, 7.12.2011. 
http://eur-

lex.europa.eu/LexUriServ/LexUriServ.do?uri=COM:2011:0870:FIN:EN:PDF

European Commission (2012). Press Release SPEECH/12/172. 'Competition policy for innovation and growth: Keeping markets open and efficient'. Joaquin Almunia. Brussels, 8 March 2012. http://europa.eu/rapid/press-release_SPEECH12-172_en.htm?locale=en

European Commission (2012a). Report on Competition Policy 2011. Brussels, 30.5.2012.

$\mathrm{df}$

http://ec.europa.eu/competition/publications/annual_report/2011/part1_en.p

European Commission (2012b). A Stronger European Industry for Growth and Economic Recovery. Industrial Policy Communication Update Brussels, 10.10.2012.

http://eur-

lex.europa.eu/LexUriServ/LexUriServ.do?uri=COM:2012:0582:FIN:EN:PDF

European Commission (2012c). Alert Mechanism Report - 2013.

http://ec.europa.eu/economy_finance/economic_governance/documents/alert_mec hanism_report_2012-11_en.pdf

European Commission (2013a) 'Recent changes in Europe's competitive landscape and medium-term perspectives: how the sources of demand and supply are shaping up'. Fellowship initiative The future of EMU. Economic Papers 485 April

2013.

http://ec.europa.eu/economy_finance/publications/economic_paper/2013/pdf/ecp4

85_en.pdf

European Commission (2013b). Macroeconomic Imbalances France 2013. http://ec.europa.eu/economy_finance/publications/occasional_paper/2013/pdf/ocp1 36_en.pdf

European Commission (2013c). In Depth Review for France. Brussels, 10.4.2013. http://ec.europa.eu/europe2020/pdf/nd/idr2013_france_en.pdf

European Commission (2014a). Press Release. Progress in industrial competitiveness per EU country. Brussels, 11 September 2014.

http://europa.eu/rapid/press-release_MEMO-14-526_en.htm

European Commission (2014b). Alert Mechanism Report 2015. Brussels, 28.11.2014. http://ec.europa.eu/europe2020/pdf/2015/amr2015_en.pdf

European Commission (2014c). Drivers and implications of the weakness of Investment in the EU. Directorate-General for Economic and Financial Affairs. Economic $\quad$ Forecasts $\quad$ Autumn 2014. http://ec.europa.eu/economy_finance/eu/forecasts/2014_autumn/box1_en.pdf

European Commission (2014d). Macroeconomic Imbalances France 2014. Brussels, 5.3.2014.

http://eur-lex.europa.eu/legalcontent/EN/TXT/PDF/?uri=CELEX:52014SC0081\&from=EN

European Commission (2015a). Report on Competition Policy 2014. Brussels, 4.6.2015.

http://ec.europa.eu/competition/publications/annual_report/2014/part1_en.pdf

European Commission (2015b). Annual Growth Survey 2015. Strengthening the recovery and fostering convergence. Brussels, 26.11.2015. 
http://ec.europa.eu/europe2020/pdf/2016/ags2016_annual_growth_survey.pdf

European Commission (2015c). 'Competition and Innovation'. Key note speech of Johannes Laitenberger (Director General DG Competition), Annual Charles River Associates Conference. Brussels, 9th December 2015.

http://ec.europa.eu/competition/speeches/text/sp2015_04_en.pdf

European Commission (2015d). 'Ex post evaluation of competition policy enforcement. What can we learn from the literature and from the experience of Competition Authorities?' European Commission Competition policy brief 2015-04, June 2015. http://ec.europa.eu/competition/publications/cpb/2015/004_en.pdf

European Parliament (2013). The contribution of Competition Policy to Growth and the $\quad$ EU $2020 \quad$ Strategy. http://www.europarl.europa.eu/RegData/etudes/etudes/join/2013/492479/IPOL-

ECON_ET(2013)492479_EN.pdf

European Parliament (2015). EU Industrial Policy: Assessment of Recent Developments and Recommendations for Future Policies. Directorate-General for Internal

Policies.

http://www.europarl.europa.eu/RegData/etudes/STUD/2015/536320/IPOL_STU(20 15)536320_EN.pdf. 